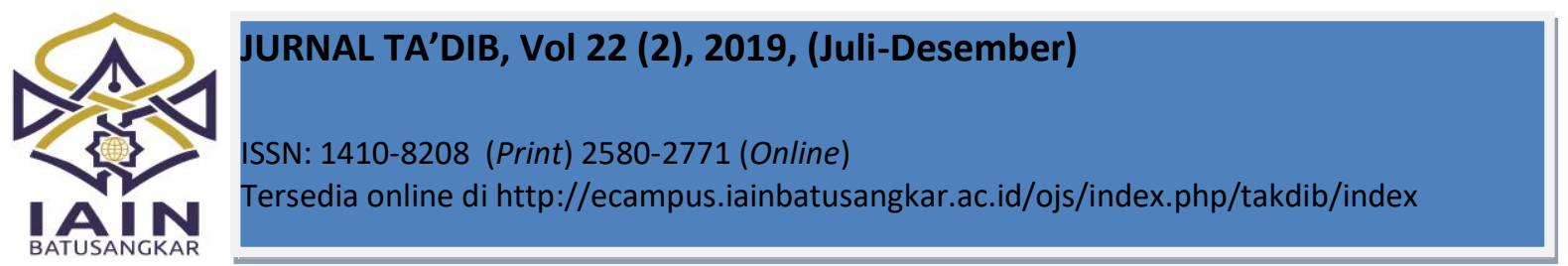

\title{
Implementation of Authentic Assessment in the 2013 Curriculum at SMA PMT Prof. Dr. Hamka Padang
}

\author{
Diki Atmarizon*) \\ English Education Study Program, \\ Universitas Nahdlatul Ulama \\ West Sumatera, Indonesia \\ Email: dikiatmarizon@gmail.com

\section{Novita Efendi} \\ SMA PMT Prof. Dr. Hamka II Padang \\ West Sumatera, Indonesia \\ Email: novitaefendi90@yahoo.com
}

*) Corresponding Author

\begin{abstract}
This research aims to describe the implementation of authentic assessment of 2013 curriculum at SMA PMT Prof. Dr. Hamka Padang. The descriptions were the kinds of assessment, the implementation of assessment and the problem encountered by the teachers. Participants were two English teachers and 7 students as the representative chosen purposively. This is descriptive research. The data were obtained from the instruments used which were observation checklist and interview guideline. The data were analyzed quantitatively and qualitatively. The result shows that 52,5\% of assessment was implemented by all English teachers. The numbers of the students became main problems besides basic knowledge, overburdened of time and classroom management. In short, the English teachers' assessment belonged to 'Fair' category. Consequently, the assessment training and workshop should be followed by the teachers. Furthermore, the researcher can widen research to know the assessment implemented by English teachers of the 2013 curriculum.
\end{abstract}

Keywords: Implementation, Authentic Assessment, 2013 Curriculum

\section{INTRODUCTION}

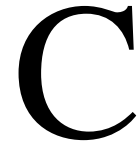

urriculum of 2013 still has been implemented by every school nowadays. The 2013 Curriculum consists of the competency which instruct the students to be capable of having good attitude and personality as well as being responsible citizen (Husamah, 2013). In teaching English, 2013 curriculum demands the teachers to prepare and proceed teaching and learning as well as assesses the students.

Kunandar (2013) defines assessment as output collection toward the students' progress along process of learning. The teacher can evaluate the students' attainment by the assessment. It is one of teacher's controls for the students' understanding of the lesson. Assessment was one effective way to see the students' achievement (Azim \& Khan, 2012) and (Mueller, 2017). Consequently, the assessment needs to be implemented in a great manner.

The teacher is necessary to implement authentic assessment in teaching. Permendikbud (2013) notes that the authentic assessment helps the teacher evaluate the preparation, process and attainment of students' learning. The authentic assessment is students' attaintive activities dealing with the apparent circumstance along the learning process by any kinds of assessments (Kunandar, 2013). The authentic assessment acquisition might be curative, enriching, deliberative and leading to learning process improvement which is suitable with assessment standard. If the standard test only 
measure the students' achievement in the end of the learning by ignoring the process, authentic assessment is expected to measure the whole process of learning (Amri, 2013) states that assessment is a strategy wich is used to measure the students' achievement in the process and product of students learning regularly, continuously, and totally.

There might be competences to be rated by the teachers along teaching learning process such as; attitude, skills, and knowledge. Indeed, in accordance with (Permendikbud, 2013), many variants of assessments can be implemented by the English teachers the forms of observation, attitude, task, project, selfassessment, portfolios and written or oral test.

Furthermore, Permendikbud (2013), there is some assessments that can be applied by the English teachers in the language teaching. The forms of assessment are, observation, attitude measurement, self-assessment, assessment of a task, written or oral test, project, and portfolios. In 2013 Curriculum, those assessments are used to measure the competence; knowledge, attitude, and, skill as following:

Firstly, self-assessment, peer-evaluation, observation, and journal are used to assess attitude. In Kunandar (2013), the assessment of attitude competence is the assessment done by the teacher to measure students' attainment of attitude competence which consist of several aspects such as receiving or attending, responding, valuing, organization, and characterization. In 2013 Curriculum, attitude is divided into two namely spiritual and social attitudes.

Secondly, written or oral test and task assignment such as homework, individual or group project are used to assess the knowledge. The assessment of knowledge is the assessment done by the teachers in order to measure students' achievement in several aspects namely knowledge, comprehension, application, analysis, synthesis, and evaluation (Kunandar, 2013). Knowledge competence comes out core competence or called (KI 3) in 2013 Curriculum. In this case, the knowledge competence reflects the concept of knowledge that should be mastered by the students.

Thirdly, the skill assessment can be accessed through performance test, project and portfolio. The assessment of skill is done by the teachers to measure students' achievement which consist of several aspects such as imitation, manipulation, precision, articulation and naturalization. Permendikbud (2013) and Mueller (2017) assert that performance was activity by asking students to perform in group or individually and project was activity by planning the project, presenting the project and giving feedback in the form fostered comments to student project. This core competence could not be separated from the knowledge competence.

Permendikbud (2013) and (Mueller, 2017) assert the process of authentic assessment implementation based on the 2013 English Curriculum should be conducted by the English teacher regularly. To implement this process in English Language Teaching, Majid (2014), Permendikbud (2013), Mueller (2017) suggest the steps by 1) identifying standard or purpose to be achieved in the lesson referred to syllabus, (2) selecting activity based on the standard or purpose, (3) designing the criteria to be assessed, (4) creating the rubric to score student, (5) planning the activity, (6) collecting the data based on the planning made, (7) organizing the collection of the data, (8) presenting the activity, (9) giving feedback in the form fostered comments to students' activity, (10) recording the result of the activity quantitatively and/ or qualitatively by using the rubric designed before, (11) analyzing the data on the rubric to see student progress and learning difficulties, (12) communicating/ reporting the analysis result of activity to students, parent, or other teachers in the school, and (13) deciding to give remedial or enrichment based on the analysis result of activity. 
Based on the procedures above, it was implied that the English teachers should apply an authentic assessment in teaching English by conducting systematic procedures which are begun with preparing, implementing, scoring, and reporting. Considering this problem, the teachers should be based on the procedures by (Permendikbud, 2013), detail procedures are proposed as follows: 1. Preparing: (Permendikbud, 2013) begins the steps of assessment by reviewing the syllabus as a guideline in creating lesson plan and designing assessment criteria. After that, teachers select appropriate assessment and develop the instruments and scoring guidelines in accordance with the kinds chosen; 2. Applying: (Permendikbud, 2013) emphasizes that the teachers begin the lesson by exploring students' learning experience. The teachers ask some questions which consider the condition and level of the students; 3. Scoring: The results of learning are analyzed by the teachers to determine progress and learning difficulties. After that, the results are reverted feedback to the students in the review form that courage them in learning; 4. Reporting: After documenting the result by using rating scale, checklist, or anecdotal records, the data collected in authentic assessment is analyzed as the report to students, parent, or other teachers in the school. According to (Permendikbud, 2013), the report should be quantitatively and/or qualitatively.

Indeed, the problems appeared in 2013 curriculum implementation. A lot of bad arrangement of authentic assessment generated to the poor system of national education. Teachers should have significant roles as the assessor; in fact the teachers could not master some techniques using authentic assessment especially in teaching English (Öz, 2014). Consequently, without adequate and proper knowledge and skills, some problems will almost certainly appear among teachers who apply the assessment.
Even, English teachers were interviewed informally. It was found that they still faced problems in the authentic assessment implementation in 2013 Curriculum concerned with the three facets that have to be evaluated by the teachers. They had to notice on every student's attitudes, skills and knowledge.

Related to the previous explanation, there were several previous researches have been done in different setting which show the 2013 Curriculum implementation in schools. First, (Lestari, 2010) concerned with the Implementation of Authentic Assessment in Public Junior High School in Malang. Second, (Wangid, Mustadi, Senen, \& Herianingtyas, 2017) dealt with The evaluation of authentic assessment implementation of Curriculum 2013 in Elementary School. Accordingly, it was attracted to hold a research in Prof. Dr. Hamka Modern Boarding School with intended to gain farther evidence about the assessment used in 2013 curriculum by entitled "Implementation of Authentic Assessment in 2013 Curriculum at SMA PMT Prof. Dr. Hamka Padang".

The objectives to be explored were to find out the kinds of authentic assessment were used by the English teachers, how the English teachers implement the authentic assessment, the problems were faced by the English teachers in using the authentic assessment.

\section{METHOD}

The research was descriptive hold by applying qualitative approach. This research reflects what the assessments used by English teachers to evaluate the students in 2013 Curriculum at Prof. Dr. Hamka Modern Boarding School. The aim of qualitative research is to reflect the research subject experience or the world occurred such as behavior, perception, motivation, action, etc by understanding phenomena (Lexy J. Moleong, 2019). The informants were two English teachers and 7 Students in $\mathrm{X}$ grade as representative. Subsequently, the instruments 
were observation checklist and interview guideline.

Observation checklist was to see what kinds of assessment applied by the teachers throughout process teaching and learning. Then the researcher gave checklist "YES" if source found, "NO" if no source available. Then, Interview was to tell the teachers' problems during assess the students guided by interview guide and recorded it.

Hereinafter, the assessment indicators from (Permendikbud, 2013) are three competences that ought to be rated by the teachers, those are knowledge, skill and attitude. Observation checklist was the data elaboration in numerical form. Meanwhile, the interview results were analyzed qualitatively. Afterwards, the criteria of each indicator were derived by combination of the Likert Scale and aspect of each indicator. The data taken from document checklist would be qualified by using (Arikunto, 2011) to see the assessment of two teachers (A and B). The formulation and scale of percentage was described as follow:

Tabel 1: Assessment criteria

\begin{tabular}{|cc|}
\hline Criteria & Percentage \\
\hline Very good & $>90$ \\
\hline Good & $71-90$ \\
\hline Fair & $51-70$ \\
\hline Poor & $31-50$ \\
\hline Very poor & $<31$ \\
\hline
\end{tabular}

$\mathrm{P}=\mathrm{F} / \mathrm{N} \times 100 \%$;

$\mathrm{P}:$ Percentage of analysis

$\mathrm{F}$ :Frequency

appeared

$\mathrm{N}$ : Number of

indicators

analyzed

The description of each assessment would show the percentage of activities conducted by the teachers. Thereafter, the data were interpreted by researcher. Then, the report was written based on that interpretation.

\section{RESULTS AND DISCUSSION Results}

Kemendikbud supposed the teachers to be aware with the three competences in 2013 Curriculum. These competences were not only to see the students' evaluation but also it demanded the teachers to be creative to make some evaluation for the students. Those competences as we could say that were attitude competence, skills competence and knowledge competence. The teachers implemented some assessments to evaluate the students through the teaching and learning process. These assessments implemented build upon the activity conducted in the classroom. (Permendikbud, 2013) argues that the forms of assessment can be implemented by the teachers in the teaching namely portfolios, observation, attitude measurement, written or oral test, self-assessment, assessment of a task, and project.

Based on the observation, the teachers have implemented the process of assessment in term of cognitive, affective, and psychomotor by using different indicators. The teachers tended to use the cognitive assessment during the teaching learning and process. The affective assessment was conducted using four criteria that were self-assessment, peerassessment, journal, and observation. Journal was rarely implemented during the teaching learning process because it was functioning to show how the graphic of each student competence in one semester. Moreover, the students also made the assessment for teacher by using students' journal. In cognitive aspect, the teacher used the instrument written test in form of essay, homework, daily test, midterm test and quiz in teaching learning process. There were considerable students to have unsuitable answer in written test and they had the same idea. In addition, there were a few lazy students hence they tried to cheat the other students. Furthermore, in implementing psychomotor assessment, the teacher was interested to see the brave students to perform in front of the classroom. After that, the teacher used portfolio once a week based on the material being taught. The project was conducted once a month because of limited time and budget. Meanwhile, especially in Portfolio-based assessments are supposed to see on students' progress dealing with their 
performance objectively and authentically (Fauziah, Abdullah, \& Hakim, 2017).

Then another teacher used observation during the teaching learning process and make journal at the end of class. All kind of assessment used different form depends on their use. In affective assessment, the teacher had self-assessment for the students whereas the students also had. The teacher would like to compare the affective assessment made by the teacher with the students. The dominant assessment would be the final mark. Next, in skill assessment, the teacher saw the result of students' performance, project (Individual or group, based on the difficulty of project and time allocation) and portfolio. All of the project would be collected at the end semester. Sometimes the students often postpone the project dealing with the many tasks from other subjects. In assessment in term of knowledge, the teacher used the written test such as reading comprehension, task assignment, daily test, etc. the written test look liked the essay and optional questions. Sometimes the teacher used the oral test but the teacher rarely to use it. The teacher assessed the students' cognitive triple on one semester such as daily test or quiz given for the teaching learning process. However, Raymond, Homer, Smith, \& Gray (2013) claim that the aspects of knowledge, attitudes and skills and should be implemented in same class circumtance to describe proficient workplace. In fact, there were many students not being centered on workgroup so that they had difficulty to do the individual task. Those students would give the remedial test.

These were ten kinds of assessment implemented in the classroom. The assessments were applied the two teachers, they are teacher A and B. To show tendency of each teacher used assessment, it would be showed by using number 1, 2, 3, 4. The number 1 means that the teachers apply one assessment, 2 means that the teachers conducted two assessment, 3 means that the teachers conducted three assessments, and 4 means that the teachers conducted four assessments during four meetings. It can be taken a look in the table 1 below:

Table 2: English Teachers' Assessment

\begin{tabular}{|c|l|c|c|c|c|}
\hline \multirow{2}{*}{ No } & \multirow{2}{*}{ Assessments } & \multicolumn{2}{|c|}{ Teachers } & \multirow{2}{*}{ Total } & \multirow{2}{*}{ Percentage } \\
\cline { 3 - 5 } & & A & B & & \\
\hline 1 & Observation & 2 & 3 & 5 & 62.5 \\
\hline 2 & $\begin{array}{l}\text { Self and Peer- } \\
\text { assessment }\end{array}$ & 1 & 2 & 3 & 37.5 \\
\hline 3 & Journal & 1 & 2 & 3 & 37.5 \\
\hline 4 & Performance test & 3 & 4 & 7 & 87.5 \\
\hline 5 & Project & 2 & - & 2 & 25 \\
\hline 6 & Portfolios & 2 & 2 & 4 & 50 \\
\hline 7 & Writing Sample & 2 & 3 & 5 & 62.5 \\
\hline 8 & Oral Interview & 2 & 3 & 5 & 62.5 \\
\hline 9 & $\begin{array}{l}\text { Constructed - } \\
\text { response item }\end{array}$ & 2 & 3 & 5 & 62.5 \\
\hline & \multicolumn{2}{|c|}{ Accumulation } & $\mathbf{4 3}$ & $\mathbf{5 2 . 5}$ \\
\hline
\end{tabular}

From the table above, the assessments can be classified as follows: first, attitude competence consisting of observation, selfand peer-assessment and journal. Second, skill competence, such as performance test, project and portfolio. Third, knowledge competence can be accessed through oral interview, writing sample and constructed - response item.

The table above shows that, there were teachers always used one kind of the assessments in every meeting. The data appeared the percentage was $87.5 \%$ of teachers used assessments performance test to know the students competence directly and the teacher could assess the students at the time. The second high percentage was observation, writing sample, oral interview, and constructed - response item. The percentage was $62,5 \%$ of the teachers tended to use observation, the teachers observed students' concern, reaction to instructional materials, or interaction with other students. Using oral test, teacher asked questions to the students related to the 
students' comprehension about material given at the time or the teacher recall the topic learned last time. Next, Assessment of writing sample and constructed - response item is easily to create by the teachers.

Then, the percentage was $50 \%$ of the teachers also care about themselves by evaluating the teacher through the students and collected the students' work to show progress over time by using portfolio assessment.

Furthermore, the percentage was $32.5 \%$ of the teachers used peer-assessment by transcribing the students' attitude qualitatively and followed the two assessments of the teachers used self - assessment to evaluate the students in unknown time and Journal assessment to evaluate the teacher by the students. The teachers almost used all kinds of assessment in a few meetings but not all assessment was easily used by the teachers and needed more time to describe it into the qualitative assessment. The last assessment was $25 \%$ of project assessments by asking students to complete project or work, working individually or in pairs. This activity is rarely to apply by the teachers because it needs wording explanation.

The teachers always identified the standard of the lesson and chose the kinds based on the standard. Although the teachers always created rubric, the teachers rarely determined the criteria to be assessed in the observation.

On interview, they confirmed that they use the rubric from the training she joined. So, they did not need to design the criteria, because the criteria had been stated in the rubric. They sometimes brought the rubric to assess the students since she could do this out of the class, and only assessed student attitude as the curriculum demand. By using the 'ready-rubric' they had, the teacher score them quantitatively or by using number. Then, the score was analyzed. She did not only analyze the observation result, but also all the score she obtained during three months of teaching.
After analyzing the result, she could communicate it to students. The teachers also said that they never report it to the parents and other teachers for the follow up.

This result of the constructed-response item implementation was confirmed to the students who learned with teachers through interview. The students confirmed that the teachers always prepared a text, and asked the students to answer the questions from the text. The questions gave by the teachers sometimes need their high thinking skill. The students also confirmed that the teacher usually check the answer of the question and gave them feedback. These results were also confirmed by the teacher on interview.

However, the teacher did not record and report the students learning result of constructed response on a rubric. It was because she only wanted to see the comprehension by checking the answer whether it was right or wrong. In short, the teacher cannot be said using constructedresponse item to the students because she considered this assessment was similar to reading comprehension by ignoring how to assess the students by using criteria to be seen on the assessment.

The teachers prepared the lesson plans which had consisted of standard and the assessment he wanted to use in learning. As the previous two teachers, they did not include the criteria and rubric he could use to assess student learning through constructed-response item. On interview, the teachers said that he used this assessment by taking the source of the text and questions from the compulsory book he used. They did not identify rubric and design the criteria because they never did it before. In teaching, the teacher prepared the text and the questions to be answered by the students by using this assessment. The teacher said on the interview that he used the book as the source, since many high-thinking level of question he could find from the book. The teachers, then, asked the students to read and 
answer the questions. The interview results indicated that that the teacher asked the students to read and answer the questions in pairs. They created it in a piece of paper. After that, the teachers and the students discussed their answer, and the teacher gave his response towards student answer as a feedback.

The interview from students of teachers showed how the teacher did the test in learning. It confirmed that the teacher provided the students with the text and gave them the question which needed their high level of thinking. Besides, the students also said that the teacher sometimes discuss the answer directly with the student, and followed by the feedback of students answers. In scoring, teachers did not record the students since he used the assessment for student exercise. The report and other further actions related to the assessment were not conducted. It indicated that the constructed respond result was not recorded by the teacher.

Teachers had problem with the number of students in the class. This problem was actually faced by teachers. The activities they gave in teaching related to the authentic assessment could not be run as well as expected, since many students she had to assess and they should have had the same opportunities in doing it. Both teachers did not think that they have no problem in reporting it. It was because they reported the result they have record in their rubric quantitatively and qualitatively.

In conclusion, those are the tendencies of each teacher for ten kinds of assessment implemented in the classroom. The percentage was $52,5 \%$ of teachers using assessment in 2013 curriculum. The teachers' assessment has not been achieved the objective of 2013 Curriculum.

\section{Discussion}

The findings reflected that the English teachers have implemented the authentic assessment properly. It was similar with authentic assessment recommended by
Permendikbud (2013), there are some assessments can be implemented by the English teachers in English language teaching. The forms of assessment are portfolio, oral interview, writing sample, observation, constructed - response item, performance test, project, journal, self \& peer-assessment. The most kinds of authentic assessment implemented by English teachers were performance assessment. On the other hand, the lower kinds of authentic assessment were project assessment.

Dealing with the authentic assessment implementation in 2013 Curriculum, there are some previous studies have been done in diverse circumstances in schools which indicated the 2013 implementation. Firstly, (Lestari, 2010) did the research entitled "A Survey on the Implementation of Authentic Assessment in Public Junior High School in Malang Municipality". In this research, she used questionnaire and interview to collect the data with 45 teachers as the samples. The finding of this study showed that the English teachers of public junior high school in Malang were still lack of knowledge about authentic assessment. In the implementation, the teachers have no enough preparation in the preparation stage. Consequently, the implementation of authentic assessment did not go smoothly. Finally, the researcher found that the most crucial problem occur in public junior high school in Malang is the limited time in performing authentic assessment in the class. Moreover, the teachers have to teach in a big class.

Furthermore, the research was conducted by Wangid et al., (2017) entitled "The Evaluation of Authentic Assessment Implementation of Curriculum 2013 in Elementary School". This research was to know the obstacles of its implementation. This was an evaluative research by a Stake's evaluation model approach. Based on the finding which collected by questionnaire, interview, observation, and document analysis, 
the teachers had implemented the 2013 Curriculum properly. It could be seen from the questionnaire with "medium" category and supported by the fact found in the field.

Even though some researchers had the similar review of authentic assessment in language teaching, more research was required to be held whether the authentic assessment in English language teaching in 2013 English Curriculum in Indonesia schools had been implemented properly. Therefore, this research perhaps intended to obtain the purpose of the research that were to find out the kinds of authentic assessment which were implemented by the English teachers to evaluate the knowledge, attitude, and skill of the students, how the English teachers implement authentic assessment, problems were encountered by the English teachers.

In this case, the teachers have applied the three aspect of assessment in term of students' attitude, knowledge, and skill throughout the process teaching and learning. First, observation, journal, and self and peerassessment are used to assess the attitude of students. From the observation assessment sheet, the teachers have assessed some of characters such as religious, honest, discipline, responsible, care, responsive, and proactive. It is supported by Kunandar (2013), the assessment of attitude competence is the assessment which done by the teacher to measure students' attainment of attitude competence which consist of several aspects such as receiving or attending, responding, valuing, organization, and characterization. Then, for the self- and peer-assessment sheet, the teachers tend to evaluate whether the students always, often, sometimes or never study hard, learn with curiosity, collect the task on time, ask the question whenever do not understand, be active in group, make a significant note, feel better to follow the learning, appreciate and respect to the parents, teacher, and friends. After that, in journal sheet, how the teachers evaluate the students by wording the positive and negative attitude qualitatively. This similar with Permendikbud (2013) asserts that students' attitude are accumulated and expressed in form of competence description by the classroom teachers qualitatively.

Second, actually the teachers have writing sample, oral interview and constructed response item such as homework, individual or group project are used to assess the students' knowledge. In this case, the teachers tend to use mid - term test, final exam, and homework to see the students' ability to cover the knowledge competence, whereas the teachers mostly like to use oral test and task assignment in the classroom. Knowledge competence comes out core competence or called (KI 3 ) in 2013 Curriculum. As explained by (Kunandar, 2013), the assessment of knowledge competence is the assessment applied by the teachers to evaluate achievement of students in several aspects namely knowledge, comprehension, application, analysis, synthesis, and evaluation.

Third, the teachers usually assess the students' skill through performance test, project and portfolio. From the performance test, the teachers assess the students' practice in front of the class while communicating step. Next, from the project, the teachers have criteria of assessment such like planning, implementation, and report. For instance, how the students prepare the clipping, implement it by searching in magazine or newspaper, and report it to the teacher. For portfolio assessment, the teachers collect the students' task or project from the beginning until the end of semester. What the English teachers implemented identically with Permendikbud (2013) and Mueller (2017) assert that performance was activity by asking student to perform in group or individually, project was activity by planning the project, presenting the project and giving feedback in the form fostered comments to student project. The assessment of skill competence is done by the 
teachers to measure students' achievement which consist of several aspects such as imitation, manipulation, precision, articulation and naturalization (Kunandar, 2013).

The lower score of authentic assessment was project or exhibition. According to the result was $25 \%$ and it could be included to fair category on implementing project although only one teacher used this assessment in teaching English. The teacher was successful implemented the assessment in her class. While teaching, the teachers hadn't implemented the assessment completely as the stages suggested by Majid (2014), Permendikbud (2013), Mueller (2017), indicators no. 5,6,7,8, and 9 .

The higher score of authentic assessment was performance based assessment. This was one of the most popular assessments applied by the teachers in English language class with $87.5 \%$ and could be included to good category on implementing performance-based assessment. All of the English teachers in this research conducted this assessment well. The teachers had prepared their rubric and recorded the student performance well. In teaching, the performances they used to give to the students were retelling activity, speech, and drama. It because of the English teachers have taken part of proposed steps in conducting performance based assessment (Permendikbud, 2013) and (Mueller, 2017) supposed that performance begins by identifying standard or purpose to be achieved in the lesson which is referred to syllabus until deciding to give remedial or enrichment based on the analysis result of performance-based assessment.

The problems faced by the teachers on results showed that the teacher had problem with the numbers of students in the class. Authentic assessment could not be run as well as expected, since many students she had to assess and they should have had the same opportunities in doing it. The teachers seemed lack of knowledge in each kind of assessment, which could be proved by there was no teacher did some authentic assessments. Besides, they were overburdened by lack of time and classroom management.

Based on upon argument, it could be resumed that the teachers have kept up the steps and established authentic assessment. Yet, the teachers were not top up to implement the authentic assessment particularly in scoring and rubric design. Class and time management and the lack of knowledge toward authentic assessment couldn't be separated as a reason of the problems.

In 2013 English Curriculum, the teachers actually have used several of authentic assessment namely portfolio, observation, writing sample, oral interview, constructed response item, project, performance test, journal, self \& peer-assessment. The percentage of using authentic assessment was $52,5 \%$. The English teachers have fulfilled enough the requirement of using assessment as a demand in the 2013 Curriculum.

\section{CONCLUSION}

The assessment has been applied on the three competences. They are attitude competence, skill competence and knowledge competence. In 2013 Curriculum, the teachers use authentic assessment as suggested by (Kemendikbud, 2014). They are observation, portfolio, oral interview, constructed response item, writing sample, performance test, project, journal, self \& peer-assessment.

Even though results showed that the assessments have been implemented by the teachers properly and they weren't ignored kinds of the authentic assessment in teaching English. The percentage of teachers' assessment was $52,5 \%$, which included into fair category.

Nevertheless, the English teachers overcome these problems, the English teacher used to use a 'ready-to-use' rubric they got form trainings in preparing assessment; they tended to do it out of the class in order all 
students could participate and had same opportunities to be involve in the activities in applying assessment; The English teachers score their students by estimating the score based on their subjective view in scoring assessment; the English teacher had the fixedformat in reporting the result which they got from school. The school gave them the softcopy of the format and formula to analyze the assessment in reporting assessment.

Besides, the implementation of assessment by English teachers was tolerable enough from the 2013 curriculum expectation. For the future, the teachers should set their strategy to monitor student progress and evaluate the shortage and prepare the rubric to record the student learning result properly. Moreover, Education Department should provide sufficient time and training toward authentic assessment in 2013 English Curriculum. Therefore, the teachers needed to enrich their knowledge about the authentic assessment in 2013 curriculum, especially in English language subject since the result showed fair performance of the teacher in implementing this.

\section{REFERENCES}

Arikunto, S. (2011). Dasar-dasar Evaluasi Pendidikan. Jakarta: Buku Aksara.

Azim, S., \& Khan, M. (2012). Authentic assessment: An instructional tool to enhance students learning. Academic Research International.

Fauziah, R., Abdullah, A. G., \& Hakim, D. L. (2017). Pembelajaran Saintifik Elektronika Dasar Berorientasi Pembelajaran Berbasis Masalah. Innovation of Vocational Technology Education.

Https://Doi.Org/10.17509/Invotec.V9i2.4 878

Husamah Husamah, Y. S. (2013). Desain Pembelajaran Berbasis Pencapaian Kompetensi - Panduan Merancang Pembelajaran Untuk Mendukung
Implementasi Kurikulum 2013. Jakarta: Prestasi Pustakarya.

Kemendikbud. (2014). Peraturan Menteri Pendidikan Dan Kebudayaan Republik Indonesia Nomor 103 Tahun 2014 Tentang Pembelajaran Pada Pendidikan Dasar Dan Pendidikan Menengah. Pedoman Evaluasi Kurikulum. Https://Doi.Org/10.1017/Cbo9781107415 324.004

Kunandar. (2013). Penilaian Autentik (Penilaian Hasil Belajar Peserta Didik Berdasarkan Kurikulum 2013). Jakarta: Pt. Raja Grafindo Persada.

Lestari, N. A. (2010). A Survey On The Implementation Of Authentic Assessment In Public Junior High Schools In Malang Municipality (Universitas Negeri Malang). Retrieved From Http://KaryaIlmiah.Um.Ac.Id/Index.Php/SastraInggris/Article/View/6798 On September 2019.

Lexy J. Moleong, D. M. A. (2019). Metodologi Penelitian Kualitatif (Edisi Revisi). Pt. Remaja Rosda Karya. Https://Doi.Org/10.1016/J.Carbpol.2013. 02.055

Majid, A. (2014). Implementasi Kurikulum 2013: Kajian Teoretis Dan Praktis. Bandung: Interes Media.

Mueller, J. (2017). Authentic Assessment Toolbox.

Öz, H. (2014). Turkish Teachers' Practices Of Assessment For Learning In The English As A Foreign Language Classroom. Journal of Language Teaching And Research.

Https://Doi.Org/10.4304/Jltr.5.4.775-785

Permendikbud. (2013). Peraturan Pendidikan Dan Kebudayaan Republik Indonesia. In Peraturan Menteri Pendidikan Dan Kebedayaan.

Raymond, J. E., Homer, C. S. E., Smith, R., \& Gray, J. E. (2013). Learning Through Authentic Assessment: An Evaluation Of A New Development In The 
Undergraduate Midwifery Curriculum. Nurse Education In Practice. Https://Doi.Org/10.1016/J.Nepr.2012.10. 006

Wangid, M. N., Mustadi, A., Senen, A., \& Herianingtyas, N. L. R. (2017). The Evaluation Of Authentic Assessment Implementation Of Curriculum 2013 In Elementary School. Jurnal Penelitian
Dan Evaluasi Pendidikan, 21(1), 104. Https://Doi.Org/10.21831/Pep.V21i1.157 79

Zul Amri. (2013). International Standard Junior High School Fledgling Teachers' Knowledge On Authentic Assessment. Retrieved From Http://Ejournal.Unp.Ac.Id/Index.Php/Isla/ Article/View/4010 
TA'DIB, Volume 22 Nomor 2, Desember 2019 